\title{
降雨時の斜面崩壊に対する限界降雨量
}

\section{PREDICTION OF SLOPE FAILURE BASED ON AMOUNT OF RAINFALL}

\author{
八木則 男* · 矢田部龍一**・榎 明 潔*** \\ By Norio YAGI, Ryuichi YATABE and Meiketsu ENOKI
}

\begin{abstract}
The total rainfall till the slope failure was investigated by numerical analysis considering the physical properties of soil. The regions which were made the object of this investigation are Kure in Hiroshima pref., Tochuyo in Ehime pref. and Kagoshima pref. . The soil of Kure and Tochuyo is made of decomposed granite soil and Kagoshima is made of shirasu. The representative physical properties of soils of failed slope was examined. The successive total rainfall causing to slope failure was obtained numerically considering the various characteristics of slope. The critical rainfall causing to slope failure increases in the order of Kure, Tochuyo, Kagoshima. The results of numerical analysis agree quantitatively with the data of slope failure.
\end{abstract}

Keywords : slope failure, prediction, rainfall, sandy soil

\section{1. まえがき}

まさ土やしらすなどの砂質土斜面では豪雨時に崩壊が 多発し，防災対策上重要な問題となっている．特に，人 命救助や交通規制を行ううえで，崩壊時刻の予測法の確 立は急を要する問題である. 崩壊時刻の予測を行う場合, 大別して, 誘因としての降雨量に着目する方法と, 崩壊 直前の斜面の変状などに着目する方法とがある.ここで は，行政サイドで多く用いられている斜面崩壊発生の限 界降雨量について考える. 豪雨時の土砂災害防止の目的 で警戒態勢や避難警報の発令などを行う基準となる降雨 量が多くの行政機関などで定められている．この基準と なる降雨量は一般に限界降雨量や危険降雨量などとよば れている。限界降雨量を設定し, 斜面災害を防止あるい は軽減する方法は, 非常に簡便かつ広範囲な地域を力 バーできるという利点があるので, その信頼度を高める ことは重要なことであると思われる.

従来, 限界降雨量は過去の崩壊資料から経験的に定め られており, 斜面を構成する土の諸物性や斜面形状など

\footnotetext{
* 正会員 工博 愛媛大学教授 工学部海洋工学科 ( ₹790 松山市文京町 3 )

** 正会員 工博 愛媛大学助手 工学部海洋工学科 (同上)

*** 正会員 工博 愛媛大学助教授 工学部海洋工学科(同上)
}

は全くブラックボックスとして扱われてきている. 土質 力学的観点からみれば, 降雨時の斜面崩壊は浸透と安定 の複合問題であり, 浸透解析と安定解析を行うことによ りその問題を解くことができる. 著者らはそのような方 法で土の諸物性を考慮して限界降雨量が数値解析的に求 められることや限界降雨量には土の強度物性よりも浸透 物性の方が大きく影響を与えるということなどをすでに 明らかにしている ${ }^{1), 21}$. 限界降雨量に与える土性や斜面 形状などの影響を解明することができれば，限界降雨量 がより物理的に意味のあるものとなり，また，その信頼 度を高めることができるものと思われる。

本報告では, 降雨時に崩壊が多発している広島県点お よび愛媛県東中予のまさ土地域と鹿児島県のしらす地域 を対象として, それらの地域の土の諸物性を考慮して数 值解析により限界降雨量を求め, 実際の崩壊資料に基ゔ く限界降雨量と比較・検討した結果を示す.

\section{2. 解析方法および斜面のモデル化}

\section{(1) 解析方法}

降雨時の斜面崩壊は雨水の浸透現象亡それに伴うせん 断抵抗とすべり力のバランスの変化により起こる. した がって, 土の物性と斜面の形状などを考慮して限界降雨 量を数值解析により求める場合, 浸透解析と安定解析を 
行う必要がある. 雨水の浸透現象は有限要素法による非 定常飽和・不飽和浸透解析により求めた。基礎方程式は 次のようである3).

$$
\operatorname{div} K(\theta) \nabla(\phi+Z)=\left[C(\theta)+\alpha S_{s}\right] \frac{\partial \phi}{\partial t}
$$

ここに, $K(\theta)$ は透水係数, $\theta$ は体積含水率, $\phi$ は圧力 水頭, $S_{s}$ は比貯留係数, $z$ は鉛直座標, $t$ は時間である. また， $\alpha$ は係数で不飽和領域で 0 , 飽和領域で 1 であり, $C(\theta)$ は比水分容量 $(=\partial \theta / \partial \phi)$ で, 不飽和土の浸透特 性曲線から求められる. 解析法の詳細およびその妥当性 は参考文献に示しているが4) 6), 室内模型実験結果と比 較した限りでは, 雨水浸透時の斜面内間隙水圧分布の経 時変化を精度よく追跡できる. また, 安定解析は円弧す ベり面を仮定する Fellenius 法により行った，安定計算 では強度定数の変化ならびに浸透解析により求めた間隙 水圧の変化と自重の変化を考慮している. 解析法の詳細 は参考文献に示している ${ }^{6)}$.

\section{（2）斜面のモデル化}

数值解析を行う場合, 斜面のモデル化は非常に重要で ある. 実際の崩壊現象に近いモデルでなければ, 解析結 果に一般性はない。降雨時の斜面崩壊といっても, その 崩壊機構や形態などにはさまざまなものがある，本研究 では，崩壊の機構としては，雨水浸透に伴う斜面内の間 隙水圧の増加が主要因となっている斜面崩壊を対象と し，崩壊の形態としてはFig. 1 に示すような斜面形状の 表層崩壊を対象としている．これは降雨時の砂質土斜面 の崩壞の大半を占める自然斜面の表層崩壊をモデル化し ている. 実際，まさ土斜面では表層すべり的な形態の崩 壊が大半であるので, このモデルで実際の現象をかなり 再現できる，また，しらす斜面ではさまざまな崩壊形態 があるといわれているが7), 最近は表土（腐葉土, 風化 しらす）が一次しらすなどからなる基岩との境界ですべ る表層すべり型の崩壊がほとんどであるということが報 告されているので8), このモデルで近年の表層崩壊は評 価できる。

Fig. 1 に示したモデル斜面を用いて解析するにあた り，次のような仮定や条件を設けている.

(1) 浸透問題および安定問題を二次元問題として扱 う.

(2) 境界条件としては底面および斜面肩の右端部は不

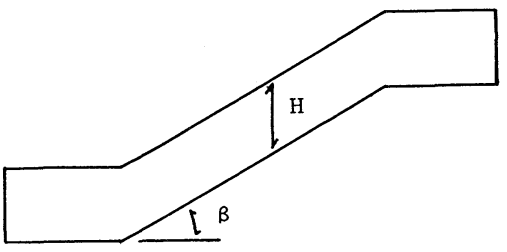

Fig. 1 Model slope.
透水, 斜面先前面は排水条件とし, 雨水は斜面表面 からのみ浸透する.

(3) 表土層厚は $0.5 \mathrm{~m}$ と $1.0 \mathrm{~m} \mathrm{の} 2$ ケースとする.

(4) 浸透物性や強度定数などは斜面内で一様である.

以下にこのような仮定を行った理由や問題点について 述べる.

まず，(1)の二次元問題として扱う場合の問題点として は, 浸透解析では集水面積などの地形条件を考慮できな いことが, また, 安定解析上の問題としては横土圧の影 響を考慮できないことが挙げられる.

二次元浸透解析では谷部で発生する大きな間隙水圧を 評価できず, 限界降雨量を考える場合, 三次元浸透解析 によるよりも危険側となる. 三次元浸透解析もなされて いるが, 非常に複雑であるので, 今回の解析は二次元で 行った.

二次元安定解析は三次元安定解析と比べて安全側とな るが, ほとんどの場合, 崩壊幅に比べてすべり深さがか なり小さいので影響は少ないと思われる. 実際, 愛媛県 のまさ土地域の崩壊では幅 $10 \mathrm{~m}$ 程度のものが最も多 く，すべり面深さの 10 倍以上である.

(2)の境界条件のうち, 斜面に平行に設けた不透水層の 仮定であるが，表土の下に基岩がありほぼ不透水と考え られる場合を除いて若干問題があるかもしれない。しら す斜面では深さ方向に表土, 風化しらす, 一次しらすと 続くのが一般的で, 透水係数は深さ方向に順次低下する. 表土の透水係数に比べてしらすの透水係数は 1 オーダー 程度は低い. しかし, 完全な不透水層というわけではな いので, 数值解析により求めた限界降雨量は実際より若 干小さめになるものと思われる. まさ土斜面は成因が花 崗岩の風化によるものなので基岩を有する場合が多く, このような場合にはこの仮定で大きな問題はないと思わ れる. また，すべり深さ $1 \mathrm{~m}$ 以下の表層崩壊では地表 からの浸透水が支配的であると考えられるので, 水の供 給は斜面表面からのみであるという境界条件でほとんど 問題はないと思われる.

(3)の表土層厚の設定であるが, 限界降雨量には表土層 の厚さが大きく影響することをすでに確かめている1). 本研究では表土層厚として上述した 2 ケースを設定して いる.

Fig. 2 は愛媛県松山市のまさ土地域において実測した 表土層厚と斜面角度の関係である. 同図には著者らの測 定結果と小川 ${ }^{9)}$ の測定結果を併せて示してある．これか ら表土層厚は斜面角度が大きくなるとともに薄くなる傾 向がみられることや崩壊が発生するような斜面角度では 厚さがほぼ $1 \mathrm{~m}$ までであることがわかる. 網干ら 10) 12) は，広島市比治山で行った調査により表土層厚は $1 \mathrm{~m}$ までであること, また，呉市，広島市における数百件の 


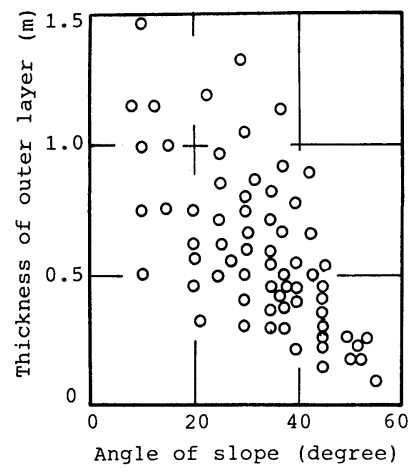

Fig. 2 Relationship between thickness of outer layer and angle of slope.

崩壊調査資料から崩壊層厚は $1 \mathrm{~m}$ までであることや斜 面角度が大きくなるにつれ崩壊層厚が若干薄くなる傾向 があることなどを明らかにしている．下川ら ${ }^{13)}$ は鹿児 島市内のしらす斜面の表土層厚の分布の調査を行い，表 土層厚は斜面上部では $1 \mathrm{~m}$ を越えるが，中腹部，下腹 部では大半が $1 \mathrm{~m}$ 以下であるという結果を得ている.

(4)の仮定についてであるが，解析に用いる土の物性と しては浸透特性曲線（保水能力を示す水分保持特性と透 水能力を示す飽和および不飽和透水係数) と強度定数(粘 着力とせん断抵抗角）ならびに初期間隙比や比重などが 必要である．自然斜面では，これらは深さ方向ならびに 平面的に非常に不均一である ${ }^{14)}$ 。このような不均一性は 当然考慮されるべきであるが，本研究では斜面内におい てすべて一様であると仮定している．ただ，数值解析に は緩い表層土の物性を用いるので，解析により求められ る限界降雨量は崩壊発生の最小降雨量に近いものとなる と思われ，土の物性を均一と仮定してもあまり問題はな いと考えられる. 斜面の土の諸物性に関しては次章で述 ベる.

斜面崩壊に与える植生の影響は大きいといわれてい る。植生は根系による補強効果など一般的には斜面を安 定にする方向の働きをし，植生のあるところでは崩壊発 生までの総降雨量は増える. 今回考えている限界降雨量 はある地域の崩壊発生までの最小降雨量であるので, 数 值解析にあたり植生の影響を考慮する必要はない. また, 斜面角度であるが，まさ土，しらす斜面とも $30^{\circ} \sim 60^{\circ}$ 程度の勾配の斜面の崩壊が多い. 今回の解析では斜面角 度は $35^{\circ}$ としている。なお，限界降雨量に与える斜面角 度の影響は透水係数や表層土厚などに比べて比較的小さ いことをすでに確かめている11.

以上, 解析の対象としたモデル斜面の形状や境界条件 およびその問題点などについて述べた.

\section{3. 物性の異なる各種砂質土からなる地域の限 界降雨量}

\section{（1）対象とした砂質土の諸物性ならびに斜面形状}

前述したように，対象とした地域は西日本における崩 壊の多発地域である広島県只地域と愛媛県の東中予地域 および鹿児島県のしらす地域である.これらの地域の土 質の諸物性は実験により求めるとともに一部は文献から も引用した。

吳地域の土質は中粒のいわゆる広島型まさ土とよばれ ているものである. 愛媛県東中予地域の土質は領家型花 崗岩の風化したまさ土で広島型に比べて粗粒である．鹿 児島の土質は火砕流堆積物のしらすである.しらすは表 層部から順に腐葉土，風化しらす，1次しらすと比較的 はっきりした土層構造をなしていることが多い，崩壊は 風化しらすと 1 次しらすの境界で発生することが多いと いわれている.

愛媛県の東中予のまさ土試料は松山市と今治市および 越智郡の斜面崩壊現場や切土斜面から採取し, 咫市のま さ土は斜面崩壊現場と表層部から採取した。 また，しら すは宮崎県えびの市の斜面から採取した。このしらすは 湖底堆積しらすである. まさ土およびしらすとも砂質土 であり，三軸試験用の不かく乱供試体を作成することは 非常に難しい．そこで，次に示す方法により不かく乱供 試体の作成を行った ${ }^{15)}$.

まず，斜面から 20 ～ $30 \mathrm{~cm}$ 角で試料をブロックサン プリングする. その際, 石膏などで周面を補強しておく. この試料を飽和度 $60 \sim 70 \%$ 程度の不飽和状態で液体窒 素を用いて低温槽の中で凍結させる．凍結させた試料を らせん溝を付けたコアカッターで円柱状に成形し，ディ スクカッターで端面の成形を行う。供試体の直径は 5 $\mathrm{cm}$ で，三軸試験を行う場合の高さは $10 \mathrm{~cm}, p F$ 試験 の場合には高さ $2 \mathrm{~cm}$ としている.

せん断試験は飽和試料を用いて圧密排水条件の三軸圧 縮試験により行った. また, 水分特性曲線 $(p F \sim \theta$ 関係) は素焼き板を用いた吸引法により脱水過程で求めてい る. 三軸試験の変位速度は $3.2 \times 10^{-2}(\mathrm{~cm} / \mathrm{min})$ で行っ た。 $p F$ 試験は吸引圧を $980 \mathrm{kPa}$ きざみで作用させ, 各 段階で定常值になるまで半日から 1 日間放置した.ここ で， $\theta$ は体積含水率である. 飽和透水係数 $\left(k_{s}\right)$ は三軸 供試体を用いた実測值であり，相対透水係数（ $k_{r}=$ $k / k_{s}: k$ は不飽和透水係数）はIrmay 法により数值的 に求めた。なお，Irmay 法はまさ土に対して適合性が良 いことが確かめられている(16),17).

以下に対象とした地域の土の諸物性を示す.

Fig. 3 にせん断抵抗角 $\phi_{d}$ と乾燥単位体積重量 $\rho_{d}$ との 関係を示す。図中，しらすに関しては著者らが求めたも 


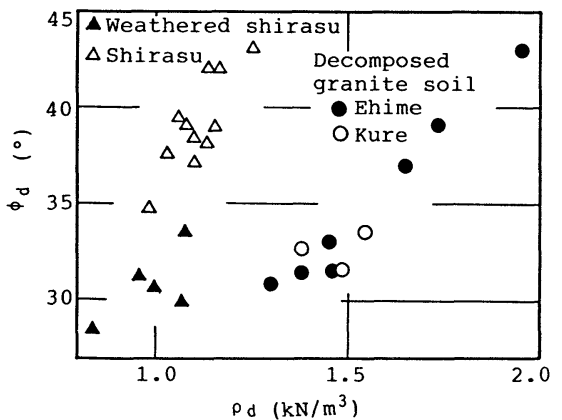

Fig. 3 Relationship between angle of shear resistance and dry density.

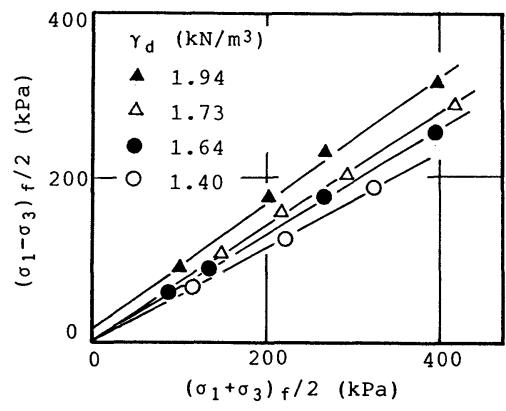

Fig. 4 Failure line.

ののほかに春山 ${ }^{18)}$, 村田ら ${ }^{19)}$, 北村 ${ }^{20)}$ の試験結果を引用 しており,一部 $\phi^{\prime}=\phi_{d}$ として示したものもある.まさ土, しらすとも $\phi_{d}$ は $\rho_{d}$ の増加に伴って, $30^{\circ}$ 前後加ら $40^{\circ}$ 以上まで変化している. しかし, 崩壊が多発している表 層土部分の $\phi_{d}$ をみると, まさ土 $\left(\rho_{d}\right.$ で $1.5 \mathrm{kN} / \mathrm{m}^{3}$ 程度 以下の部分), しらす (風化しらす) とも $30^{\circ}$ 程度である.

飽和状態における粘着力 $c_{d}$ に関して述べる．Fig. 4 に示すように風化の進んだまさ土は飽和すれば見掛けの 粘着力は消失し, ほぼゼ口となる.これは広島型まさ土, 領家型まさ土とも共通の性質であり，今回試験した試料 でもいずれもほぼゼロであった.しらすの粘着力 $c_{d}$ と $\rho_{d}$ の関係を Fig. 5 に示す. 1 次しらすの粘着力は 10 $30 \mathrm{kPa}$ 程度である.これからすれば 1 次しらすでは崩 壊層厚がせいぜい $1 \mathrm{~m}$ 程度の表層崩壊は非常に起こり にくいことがわかる．風化しらすでは粘着力は小さくな るが，ゼロではないようである.

飽和透水係数 $k_{s}$ 之 $\rho_{d}$ の関係を Fig. 6 に示す。この図 には著者らが求めたもの以外にも広島のまさ土の透水係 数の一部は網干ら ${ }^{21)}$ がまとめたものを，また，しらす の透水係数の一部は北村 ${ }^{20)}$, 伊勢田ら ${ }^{22)}$ のものを引用し ている.

Fig. 7 に浸透特性曲線を示す. まさ土の乾燥単位体積 重量は松山の試料が $1.38\left(\mathrm{kN} / \mathrm{m}^{3}\right)$, 㺯のものが 1.37 $\left(\mathrm{kN} / \mathrm{m}^{3}\right)$, また, 風化しらすの乾燥単位体積重量は

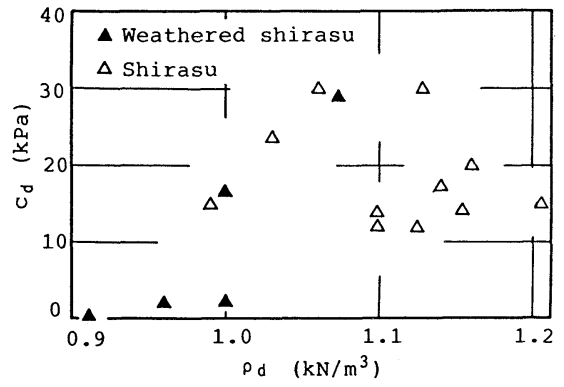

Fig. 5 Relationship between cohesion and dry density.

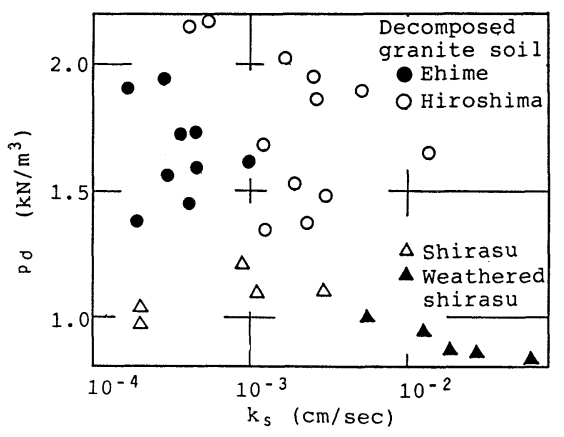

Fig. 6 Relationship between coefficient of permeability and dry density.

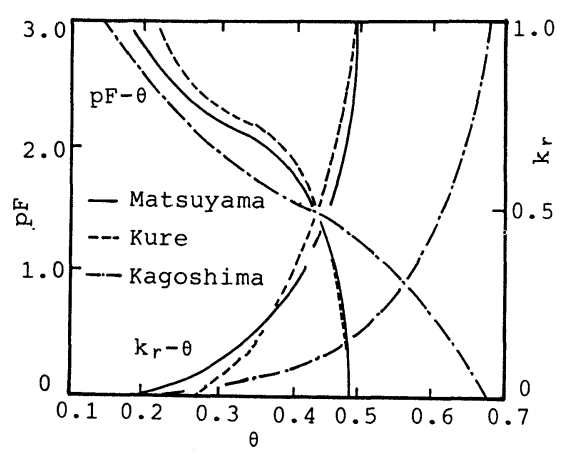

Fig. 7 Seepage characteristic curve.

$1.03\left(\mathrm{kN} / \mathrm{m}^{3}\right)$ といずれも表層の緩い土である.

以上述べてきたまさ土としらすの物性の中で，降雨時 の斜面崩壊に関係すると思われる特徴的なことを挙げる と以下のようである.

(1) 強度定数で特徵的なことは, まさ土では飽和状態 で粘着力 $c_{d}$ がほぼゼロであるということである.しら すは 1 次しらすではかなり大きな $c_{d}$ をもち，風化しら すでも飽和時に若干の $c_{d}$ をもつようである。なお，ま さ土は不飽和状態では主にサクションに起因する見掛け の粘着力をもっている．せん断抵抗角はまさ土，風化し らすともに $30^{\circ}$ 前後であまり差はみられない。なお, $30^{\circ}$ 強という摩擦角は砂質土の中では非常に小さい. 強 
度定数の点からみると, 風化しらすが飽和時にも若干の $c_{d}$ をもつという点でまさ土よりも降雨に強い土といえ る.

表層崩壊の場合, 崩壊層厚はせいぜい $1 \mathrm{~m}$ 程度, す ベり面での有効鉛直土被圧も高々 $10 \mathrm{kPa}$ 程度であり, せん断抵抗角によるせん断抵抗力は数 $\mathrm{kPa}$ 以下である. したがって, まさ土の不飽和時に $10 \mathrm{kPa}$ 程度の粘着力 をもつものが, 飽和すればほぼゼロになるという性質は, 降雨時の斜面崩壊の主要因の 1 つであるといえる.また, 1 次しらすでは $c_{d}$ が大きいことと $\rho_{d}$ が小さいことも あって表層崩壊は非常に起こりにくい.

(2) 愛媛県東中予と広島のまさ土では, 飽和透水係数 が異なり，広島のまさ土の方が 1 オーダー程度透水性が よい. また，風化しらすの透水性はさらによく， $k_{s}=$ $10^{-2}(\mathrm{~cm} / \mathrm{s})$ のオーダーである.ただし，1次しらすは $10^{-3}$ から $10^{-4}(\mathrm{~cm} / \mathrm{s})$ のオーダーであり，まさ土とあま り変わらない。

降雨の浸透は地表からの不飽和鉛直浸透と浸潤前線が 不透水層に達した後の飽和帯の形成に伴う間隙水圧の増 加という現象からなっている。降雨時の斜面崩壊の要因 の 1 つとして飽和帯の形成に伴う間隙水圧の増加が挙げ られるが ${ }^{11}$, 飽和帯が形成され始めるまでの不飽和鉛直 浸透に非常に長い時間を必要とする. したがって, 透水 性の面からは, 浸透しやすいという意味ではしらすが最 も降雨に対して弱く, 松山のまさ土が最も強いというこ とになる（ただ，透水係数が大きければ，それだけ水も 抜けやすく, 間隙水圧も発生しにくくなるので一概には 断定できない).

(3) まさ土としらすでは $p F \sim \theta$ 関係が異なり，低 $p F$ 領域ではしらすの体積含水率がまさ土のそれよりか なり大きく, $p F$ が大きくなれば逆にしらすの方が小さ くなる．この点から考えれば，しらすの方が飽和するま で多量の水を必要とするということになり，降雨に対し て強い斜面ということになる. 実際，一般的な自然含水 状態と思われる $p F=2$ の状態から飽和するまでにしら すではまさ土の 4 倍程度の水量を必要とする。なお， Fig. 7 に示したデー夕は多くの試料に基づく平均值的な ものではないが，緩いまさ土と風化しらすの傾向は表わ していると思われる.

(4)しらすの乾燥単位体積重量はまさ土のそれと比べ て非常に小さい，乾燥単位体積重量が小さい土はパイピ ング破壊的な崩壊が発生しやすい，なお，乾燥単位体積 重量の大小のみでは, 斜面崩壊に対して安全側とも危険 側亡もいえない。斜面角度, せん断抵抗角, 発生間隙水 圧とも関連して崩壊に対して与える影響が決まる.

限界降雨量を設定する場合に先行降雨量というパラ メーターが重要であることが知られているが，先行降雨
量は力学量に言い換えれば斜面の飽和度というようなも のになる. 著者らは松山のまさ土斜面において土の間隙 圧 (飽和度) の長期観測を行っている ${ }^{11,23)}$. Fig. 8 に観 測より求めた地盤内のサクションの経時変化の一例を示 す。これから, 降雨時には浸潤前線の降下とともにサク ションが減少し, 降雨が止めば徐々にサクションは増加 していくこと, また, 無降雨時にはサクションは表層部 で大きく, 梁くなるにつれて小さくなるような分布をし ていることなどがわかる．これらの観測結果などをもと に地盤の間隙圧と無降雨日数の関係を Fig. 9 に示す.

Fig. 9 で地盤の間隙圧は $p F$ で示している. 地盤の間陌 圧は深さ方向に変化しているので, 初期値としては当然 このような分布を考慮する必要がある.しかし，そうす れば計算が複雑になるので, 今回は地盤内の間隙圧は深 さ方向に一様とした，そして，初期値として Fig. 9 に実 線で示したような関係を仮定し, サクション $2.94 \mathrm{kPa}$ (無降雨日数 0 日), $9.8 \mathrm{kPa}$ ( 5 日), $18.6 \mathrm{kPa}$ (10日), $39.2 \mathrm{kPa}$ (14 日）とした. Fig. 9 の関係は松山のまさ 土斜面での実測值であり, 咫のまさ土斜面と鹿児島のし らす斜面とでは当然異なってくるであろうが，観測資料 がないので便宜的に Fig. 9 の関係を代用している.

土の強度定数としては，せん断抵抗角は Fig. 3 を参考 にして $35^{\circ}$ とした. 粘着力はまさ土でゼロとしたが, し らすでは若干の $c_{d}$ をもつようであるので $1.96 \mathrm{kPa}$ と

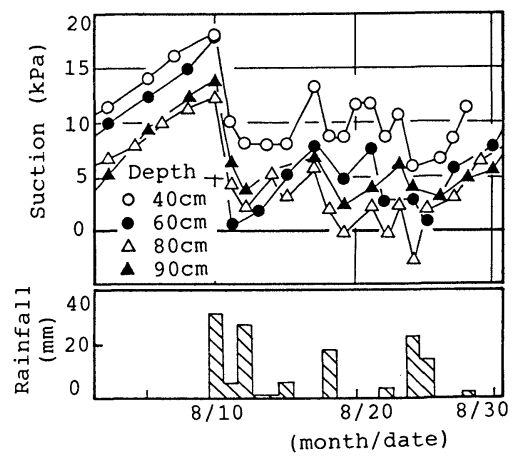

Fig. 8 Changes of pressure head and rainfall with time.

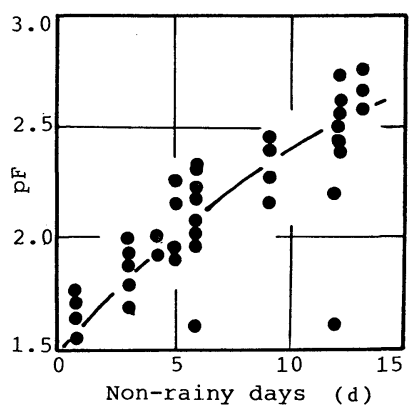

Fig. 9 Relationship between suction and non-rainy days. 
ゼロの場合に対して計算を行い, 粘着力の影響を調べた. 乾燥単位体積重量 $\rho_{d}$ はまさ土で $1.4\left(\mathrm{kN} / \mathrm{m}^{3}\right)$, しらす で $1.0\left(\mathrm{kN} / \mathrm{m}^{3}\right)$ とした. 飽和透水係数は Fig. 6 を参考 にして, 愛媛県東中予地域では $3.0 \times 10^{-4}(\mathrm{~cm} / \mathrm{s})$, 呉地 域では $3.0 \times 10^{-3}(\mathrm{~cm} / \mathrm{s})$ ，鹿児島のしらす地域では 3.0 $\times 10^{-2}(\mathrm{~cm} / \mathrm{s})$ と 1 オーダーずつ変えた．浸透特性曲線 はFig. 7 に示したものを用いた. 表土層厚は前述したよ うに $1.0 \mathrm{~m} と 0.5 \mathrm{~m}$ の 2 通り, また, 斜面角度は $35^{\circ}$ と した. 降雨強度は $20 \mathrm{~mm} / \mathrm{h}$ で一定としている。降雨強 度を $20 \mathrm{~mm} / \mathrm{h}$ としたのは，一般的に $20 \mathrm{~mm} / \mathrm{h}$ を越える ような降雨のときに多く崩壊が発生しているという理由 による.

なお，しらす斜面では深さ方向に風化しらすに続いて 1 次しらすがあるのが一般的なので, 基岩の透水性に関 して不透水の場合と風化しらすより 1 オーダー低い透水 係数をもつ場合の 2 通りについて計算し，基岩の透水性 の影響に関しても検討している.

\section{(2) 解析結果と崩壊資料との比較}

Fig. 10, 11 におのおの表土層厚 $0.5 \mathrm{~m}$ と $1.0 \mathrm{~m}$ の場 合の数值解析より求めた崩壊発生までの総降雨量と無降 雨日数の関係を示す。この関係は，ある無降雨日数に対

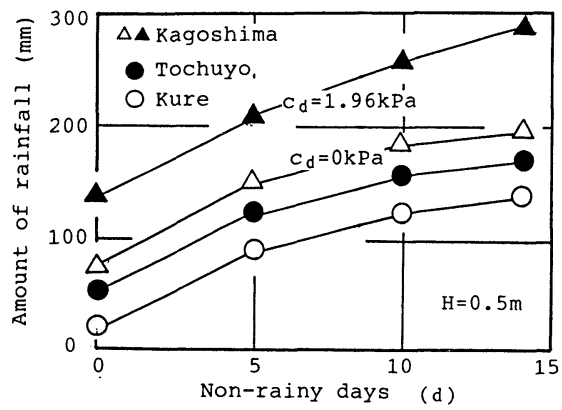

Fig. 10 Relationship between critical rainfall of slope failure and non-rainy days by numerical analysis.

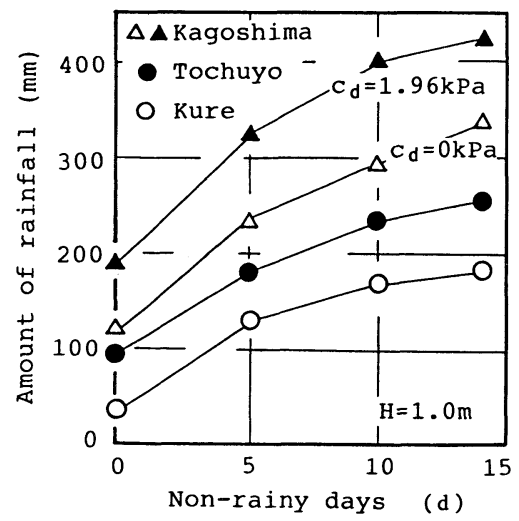

Fig. 11 Relationship between critical rainfall of slope failure and non-rainy days by numerical analysis.
応する間隙圧を初期值として浸透解析を行い, そして, それをもとに安定解析を行い, 安全率が 1 となるまでの 経過時間から総降雨量を求めて得られたものである. 風 化しらすは飽和しても若干の粘着力を有していると思わ れるので, $c_{d}=1.96 \mathrm{kPa}$ とゼロの場合に対して計算し ている. まさ土の粘着力はゼロとしている. 粘着力がゼ 口あるいは $1.96 \mathrm{kPa}$ という条件は植生などを考えると 非常に小さいと思われるが，ここで考えている限界降雨 量は崩壊発生の最小雨量ということなのでこの值で計算 している.

数值解析により求められた限界降雨量について考察す る前に若干の問題点を述べておく.

1 つは表土層厚の問題である. 表土層厚が $1.0 \mathrm{~m}$ の場 合は $0.5 \mathrm{~m}$ の場合と比べて限界降雨量は 1.5 倍程度も 大きく, 限界降雨量に与える表土層厚の影響は非常に大 きいことがわかる. 斜面のモデル化のところで述べたよ うにまさ土やしらす斜面では表土層厚 $1.0 \mathrm{~m}$ 末満のも のが多い. したがって, 表土層厚 $1.0 \mathrm{~m}$ とすると限界 降雨量を若干過大に, $0.5 \mathrm{~m}$ では若干過小に推定するこ とになると思われる.

また, しらすの粘着力の問題であるが, 粘着力ゼロの 場合の限界降雨量と比べて粘着力を $1.96 \mathrm{kPa}$ とわずか 増すと限界降雨量は 1.4 1.5 倍も大きくなっており, しらす斜面の限界降雨量は粘着力に対して非常に鋭敏で ある. まさ土の場合も粘着力の増加とともに限界降雨量 は大きくなるが，しらすの場合に比べて影響は小さい2). これは，まさ土斜面としらす斜面における間隙水圧の経 時変化の特性が若干異なっていることが影響している. すなわち，しらす斜面ではまさ土斜面と比べて透水係数 が大きいので浸潤前線が基岩に達するまでの時間は短 い.しかし，浸潤前線が基岩に達してから後は，しらす の間隙比が大きく, 飽和するまで多くの水を必要とする という性質と透水係数が大きく水が抜けやすいという性 質とにより間隙水圧の増加速度はまさ土のそれと比べて かなり小さい. したがって, しらすの粘着力の増加に見 合うだけ間隙水圧が増加するまでに多くの時間を必要と し, 崩壊発生までの降雨量は多くなる.

基岩の透水性の問題であるが, 数値解析による限界降 雨量は基岩を不透水層と仮定して求めているが，実際は 基岩も透水性を有している場合がある. 特に, しらす地 域の表土すべりで基岩が 1 次しらすである場合にその影 響は顕著であると思われる. Fig. 12 は風化しらす斜面 のすべりを対象として基岩の部分を不透水とした場合と 表土の風化しらすの透水係数よりも 1 オーダー小さい透 水係数を与えた場合の限界降雨量を示したものである. これから, 基岩に風化しらすの透水係数より 1 オーダー 小さい透水係数を与えた場合の限界降雨量は基岩を不透 


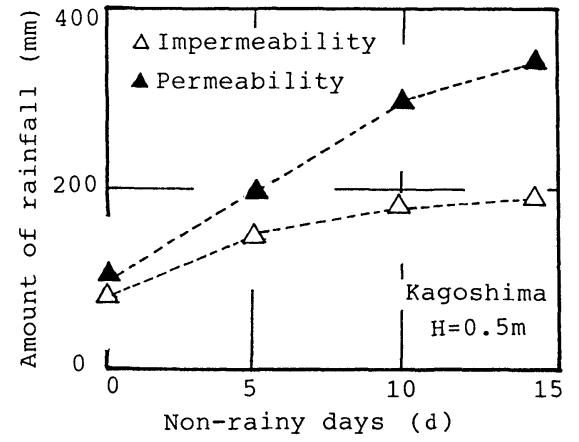

Fig. 12 Influence of permeability of base rock on critical rainfall of slope failure.

水と仮定した場合のそれと比べて $1.2 \sim 1.7$ 倍程度増加 していることがわかる，以上のように，限界降雨量は表 土層厚, 粘着力, 基岩の透水性によりかなり変化する.

ところで，斜面のモデル化および土の物性で述べたこ とから考えれば，まさ土斜面およびしらす斜面において も表土層厚 $0.5 \mathrm{~m}$, 粘着力ゼ口, 基岩を不透水とした場 合にはほぼ下限の限界降雨量が得られる。

数值解析より求められる限界降雨量は, 尅のまさ土地 域が最も小さく，東中予のまさ土地域，鹿児島のしらす 地域の順に大きくなる。これから同じまさ土地域であっ ても尅の方が雨に対して非常に弱い地域であることがわ かる. この東中予地域と呉地域の限界降雨量の相違は,

Fig. 6 に示したように, 愛媛の東中予地域と広島のまさ 土地域とでは強度定数と間隙比がほぼ同じであっても飽 和透水係数が 1 オーダー程度異なることが特に影響して いると思われる. しらす地域の限界降雨量は, 今回解析 したまさ土地域のそれより大きい。この計算では，まさ 土は非常に崩壊しやすいという結果になっている，それ は, まさ土の飽和透水係数が比較的良く, 保水性が小さ いという性質によって短時間で，より少ない降雨で飽和 するということ，また，飽和すれば不飽和時に有してい た $c_{d}$ がほぼゼロとなるという性質によるものと思われ る. しらす斜面の限界降雨量の方がまさ土斜面の限界降 雨量よりも大きいのは，前述したように保水性と透水性 の関係で間隙水圧の増加速度がまさ土の場合と比べて小 さいという理由による，実際，体積含水率についてみる と初期間隙圧として一般的な $p F=2(-9.8 \mathrm{kPa})$ を基 準として考えれば飽和するまでしらすではまさ土の 4 倍 程度の水量を必要とする.

Fig. 13 に実際の崩壊資料 $\left.{ }^{24)} 28\right)$ より求めた崩壊発生日 前の 1 週間の総降雨量と崩壊発生日の日雨量の関係を示 す. なお, 日雨量は崩壊発生時刻前の 24 時間雨量とし ている. 斜面崩壊は一度の連続降雨期間中に数日にわ たって発生する場合が多いが, 第 1 回目の崩壊が発生し

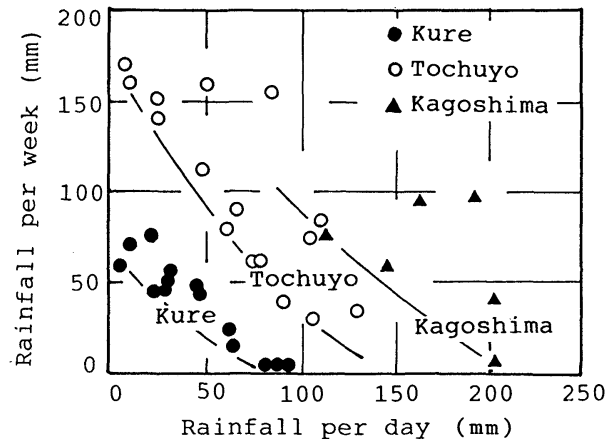

Fig. 13 Relationship between rainfall per week and rainfall per day of failed slopes.

たときについてだけ整理してある．したがって，Fig.13 は崩壊が発生する最小降雨量を示していることになる. なお，鹿児島県の資料に関しては，しらすの風化した表 土が表層すべりを起こしたものを対象とし，また，記載 したもの以外にももっ之降雨量の多い崩壊例も何例かあ るが, それは省略している。これから東中予地域, 颚地 域では図に実線で示したような限界雨量曲線が得られる ようである．鹿児島県のしらすの表土すべりの場合， $200 \mathrm{~mm}$ 程度が限界雨量と思わ机るが, ばらつきが非常 に大きい．このばらつきは鹿児島県のしらす地域といっ ても, 場所が変わ机ば斜面の土性や斜面形状がかなり異 なるからであると思われる.

ここで, 数值解析による限界降雨量と崩壊資料に基づ く限界降雨量との比較を行う.

崩壊資料より求めた限界降雨量は, 尅地域が最も小さ くて $50 \mathrm{~mm}$ から $100 \mathrm{~mm}$, 続いて東中予地域で $100 \mathrm{~mm}$ から $200 \mathrm{~mm}$ である. 鹿児島では, 吳地域, 東中予地域 と比較すれば明らかに大きく，200 mm を越えると崩壊 が発生するようである. なお, 春山も斜面崩壊発生限界 雨量曲線を崩壊発生前の 1 時間雨量と崩壊発生時までの 累加雨量との関係で整理して求め, 累加雨量 $200 \mathrm{~mm}$ を 越えるころから崩壊が発生し始めることを示してい $ろ^{29)}$.

数値解析による崩壊発生までの総降雨量は呉地域, 東 中予地域, 鹿児島地域の順に大きく, 表土層厚 $1.0 \mathrm{~m}$ でそれぞれ 50 180 mm, 100 250 mm, 120 330 mm ( $c_{d}$ $=0 \mathrm{kPa}$ の場合), 表土層厚 $0.5 \mathrm{~m}$ でそれぞれ $20 \sim 130$ $\mathrm{mm}, \quad 50 \sim 170 \mathrm{~mm}, 80 \sim 200 \mathrm{~mm}$ ( $c_{d}=0 \mathrm{kPa}$ の場合) となっている.

崩壊資料より求めた限界降雨量亡数值解析より求めた 崩壊発生までの総降雨量とではパラメーターが異なるの で厳密な比較はできない，ただし，数值解析で無降雨日 数 7 日以上の場合は, Fig. 13 では先行降雨ゼロに相当 し, また, 無降雨日数が 7 日以下の場合は先行降雨があっ 
た場合で，無降雨日数が小さくなるにつれて先行降雨量 としては増える方向にあると考えてよい。このような観 点から数值解析結果と崩壊資料より求めた結果を比較す ると解析結果は東中予地域と吳地域の崩壊資料より求め た限界降雨量の相違を比較的よく説明しているようであ る. また，しらす地域でも解析結果は崩壊資料より求め た限界降雨量を一応説明できているが, 崩壊資料より求 めた限界降雨量は表土層厚 $0.5 \mathrm{~m}$, 粘着力ゼ口, 基岩を 不透水とした場合の数值解析結果よりかなり大きい。こ れは実際のしらす斜面の多くは基岩に透水性があるこ と, 粘着力がゼロでないことなどが影響していると思わ れる.なお, 崩壊資料から求めた限界降雨量では先行降 雨量として 1 週間降雨量を用いたが, 数值解析に基づく 限界降雨量に同様なパラメーターを使用するには斜面内 の間隙圧（あるいは飽和度，含水比）と降雨量に関する もっと長期間の現地観測デー夕を必要とする.

これまで, その利便性から降雨時の斜面崩壊予測に多 用されていた限界降雨量は過去の崩壊資料をもとにした 非常に経験的色彩の濃いものであった。しかし, 今回の 解析により, 限界降雨量は土の諸物性を考慮した数值解 析により定量的に求められること, また, 土性が限界降 雨量に与える影響を定量的に評価できる可能性があるこ とが明らかになった。

限界降雨量は, 地域の代表値として使用されている. しかし, 地域内にはさまざまな斜面が存在し, 崩壊の危 険性は斜面ごとに異なる. 今回の解析結果からみれば, 表土層厚，透水係数，粘着力なゼが限界降雨量に与える 影響は特に大きい. 数值解析によって, 土性や斜面形状 を考慮した限界降雨量を地域ごとに求めておけば，今ま で以上に降雨時の斜面崩壊予測に役立つと思われる.

今後, 今回示した手法を他の多くの地域に適用して, その妥当性を検討することが必要である.

\section{4. あとがき}

降雨による斜面崩壊発生時期の予測法の 1 つとして多 用されている限界降雨量に土質力学的な意味付けを行 い, より合理的な予測法とする目的で, 吳および東中予 のまさ土地域と鹿児島県のしらす地域を対象として数伹 解析により限界降雨量を求め, 崩壊資料に基づく限界降 雨量との比較を行い, その適応性を検討した. 本研究に より得られた結論は次のようである.

（1）愛媛県東中予之広島県吳のまさ土地域および鹿 児島県のしらす地域を対象として，土の諸物性を考慮し た数值解析により限界降雨量を求めた。 そして, この数 值解析結果と実際の崩壊資料に基づく限界降雨量とが比 較的よく一致した。したがって,このような数值解析に より, 従来経験的に与えられていた限界降雨量に力学的
意味付けを行うことができ，また，限界降雨量は降雨に よる斜面崩壊発生時期のより合理的な予測法となり得る ことが明らかになった。

（2）しらす地域の限界降雨量と比較して, まさ土地 域のそれの方が小さい，これは，しらすの保水性がまさ 土の保水性と比べて非常に大きいということが特に影響 している．また，まさ土が降雨に非常に弱いのは，透水 性が比較的良いこと, 保水性が小さいこと, 飽和時に粘 着力が消失するという性質を併せもつからである.

本研究を行うにあたり，しらすの採取に関しては鹿児 島大学工学部 北村良介先生に, 颚のまさ土の採取に際 しては広島県吳土木事務所にお世話になった。崩壊資料 は吳高専 小堀慈久先生, 吳市消防局ならびに愛媛県砂 防課に, また, 実験, 計算に際して, 愛媛大学工学部海 洋工学科技官 二神 治氏, 元・愛媛大学大学院生 渡邊 晃史氏 (現・不動建設 (株)), 元・愛媛大学工学部生 中島大介氏 (現・近畿電気工事(株))にお世話になった. 記して関係各位に感謝致します。

本研究を行うにあたり一部, 昭和 62,63 年度文部省 科学研究費(重点領域研究(2),代表：鳥取大学 道上教授) を使用した。なお,数值計算は愛媛大学情報処理センター のFACOM M-180 IIAD を使用した。

\section{参 考 文 献}

1）矢田部龍一・榎 明潔・八木則男：危険降雨量に基づく 斜面崩壊発生時期の予知に関する検討，地すべり，第 23 巻, 第 2 号, pp. 1 7, 1986 .

2）矢田部龍一・八木則男・榎 明潔：降雨による砂質土斜 面の崩壊発生時期の予知法に対する検討, 土木学会論文 集, 第 376 号, pp. 297 305, 1986.

3）赤井浩一・大西有三・西垣 誠: 有限要素法による飽和 不飽和浸透流の解析, 土木学会論文報告集, 第 264 号, pp. $87 \sim 96,1977$.

4）八木則男・矢田部龍一・山本浩司：雨水浸透による斜面 崩壊, 土木学会論文報告集, 第 330 号, pp. 107 114, 1983.

5) Yagi, N., Yatabe, R. and Yamamoto, K. : Slope failure mechanism due to seepage of rain water, Proc. 7th ARCSMFE, Vol. 1, pp. 382 386, 1983.

6）矢田部龍一・榎 明潔・八木則男：降雨浸透を考慮した 斜面安定解析法の検討, 地すべり, 第 22 巻, 第 3 号, pp. 1 7, 1985.

7）春山元寿・下川悦郎：昭和 47 年 $6 \cdot 7$ 月豪雨によって 鹿 児島県内に発生した斜面崩壊の実態, 土と基礎, 第 21 巻, 第 7 号, pp. 13 16, 1973.

8）北村良介・地頭薗隆・田口博文：しらす斜面崩壊機構と 防災システム，斜面崩壊および地すべりの予知と対策に 関するシンポジウム発表論文集, pp. 3〜10，1988.

9）小川 滋：山林地における山腹崩壊の生起確率の算定法 について, 第 19 回自然災害科学総合シンポジウム講演要 旨集，pp. 149〜150，1982.

10）網干寿夫・中之堂裕文：マサの斜面崩壊時におけるせん 
断強度について, 第 11 回土質工学研究発表会発表講演集, pp. $737 \sim 740,1976$.

11）網干寿夫・小堀慈久：貫入試験值による斜面風化状況調 查一広島市・吳市の場合一, 第 36 回土木学会中国四国支 部研究発表会講演概要集, pp. 169 170, 1984.

12）網干寿夫・小堀慈久：まさ土斜面崩壊地域の比較調査一 広島市及び, 吳市の場合一, 土木学会第 43 回年次学術講 演会講演概要集第 3 部, pp. 210 211, 1988.

13）下川悦郎・地頭薗隆：しらす急斜面における表層土の分 布と崖くずれの周期性, 科学研究費 (重点領域研究(2), 代表者 北村良介）研究成果報告書, pp. 5 17, 1988.

14）風化残積土地盤の物理 - 力学的性質研究委員会:サンプ リングと採取資料の品質評価（その 2 ), pp. 5 14, 風 化残積土に関するシンポジウム発表論文集, 1988.

15）八木則男 · 矢田部龍一：不攪乱まさ土のせん断特性と微 視的考察, 土木学会論文集, 第 364 号, pp. 133 141, 1985.

16）吉田 勲・筑紫二郎：マサ土の透水性及びせん断強度特 性, 科学研究費 (自然災害特別研究(1), 代表者 網干寿夫) 研究成果報告書, pp. 53 67, 1986.

17）矢田部龍一：まさ土地帯における降雨時の斜面崩壊の機 構と予測に関する研究, 京都大学学位論文, pp. 20 25, 1986.

18）春山元寿： $c$ と $\phi$ を考える 7. シラス, 土質工学会, $N$ 值および $c$ と $\phi$ の考え方, pp. 95〜102, 1976.

19）村田秀一・山内豊聡：乱さないシラスの強度特性の要因 について, 土質工学会論文報告集, 第 17 巻, 第 3 号, pp. 81 92, 1977.
20）北村良介：しらす斜面崩壊の発生機構に関する研究, 昭 和 62 年度文部省科学研究費補助金 <重点領域研究(2) > 研 究成果報告書, 1988 .

21）網干寿夫・門田博知・吉国 洋・中ノ堂裕之：マサ土斜 面崩壊の予測と危険力所の類型化に関する基礎的研究, 文部省科学研究費, 自然災害特別研究報告書, pp. 37 55, 1976.

22）伊勢田哲也・新 英司・稲又政俊・調 修二：しらす斜 面における降雨浸透特性について, 土木学会第 43 回年次 学術講演会講演概要集第 3 部, pp. 900 901, 1988.

23）矢田部龍一・八木則男・榎 明潔：降雨による斜面崩壊 予測のための地盤内サクションの測定, 不飽和土の工学 的性質研究の現状シンポジウム発表論文集, pp. 301 $306,1987$.

$24 ）, 25 ）$ 愛媛県土木部砂防課：昭和 55,57 年度急傾斜地崩 壊調查資料, 1981，1983.

26）呉市消防局 : 呉市におけるがけくずれの予知とその警報 の時期について, 1968.

27）藤本 廣・落合英俊・林 重徳 - 北村良介・中村淳子： 斜面崩壊に対する土質工学的アプローチ, 突発災害研究 成果, No. B-61-1, pp. 46 60, 1987.

28）春山元寿 : 豪雨による南九州の斜面崩壊, 自然災害科学 資料解析研究, Vol.1, pp. 80 88, 1974.

29）春山元寿：南九州しらす地帯の豪雨による斜面崩壊, 土 と基礎, Vol. 31, No.1, pp. 105 110, 1983.

(1989.5.1 - 受付) 